International Journal of Agriculture, Environment and Bioresearch

Vol. 5, No. 05; 2020

ISSN: $2456-8643$

\title{
OPTIMIZATION OF IR 42 RATOON TILLERS THROUGH HEIGHT AND INUNDATION TIME TO INCREASE GROWTH AND YIELD OF RATOON RICE
}

\author{
Yunis Marni ${ }^{1}$ Auzar Syarif ${ }^{1}$, M.ZulmanHarja Utama ${ }^{2}$ dan Gustian ${ }^{1}$ \\ ${ }^{1}$ Faculty of Agriculture Andalas University \\ ${ }^{2}$ Faculty of Agriculture Taman Siswa University \\ Padang, Indonesia. \\ Marniyunis@gmail.com
}

https://doi.org/10.35410/IJAEB.2020.5560

\begin{abstract}
This research was aimed to determine the optimization of ratoon tillers of IR 42 varieties through height and time of inundation which aims to increase the growth and yield of ratoon rice. This study used a completely randomized experimental design (CRD) which consisted of two factors. The first factor is inundation height (T0: $0 \mathrm{~cm}$ from the ground, T1: $5 \mathrm{~cm}$ from the ground, T2: $10 \mathrm{~cm}$ from the ground, T3: $15 \mathrm{~cm}$ from the ground) and the second factor is the inundation time (P1: Week 5 after pruning, P2: 6th week after pruning, P3: 7th week after pruning, P4: 8th week after pruning).

The results of this study stated that the starting time of inundation affected the maximum tillers and productive tillers. The taller the tillers the longer the inundation begins. The highest productive tillers were in the 5th week of inundation. The best height of inundation for the yield of IR. 42 ratoon rice grain was $10 \mathrm{~cm}$ from the ground.
\end{abstract}

Keywords: ratoon rice, IR-42,Height of inundation, Time of inundation

\section{INTRODUCTION}

Ratoon is a shoot that grows on a rice stump that has been harvested which is producing for the second time [1]. Ratoon cultivation is widely used in several countries, but production tends to be low, namely $40-75 \%$ of the main crop [2]. However, ratoon use should be effective, efficient and economical because it does not cultivate the land, does not use seeds because seeds are expensive. and no need for planting, also saving costs and labor. In addition, ratoon rice is also sustainable because the straw as a source of organic material is not burned by farmers.[3]

Ratoon maintains the genetic purity of hybrid varieties by vegetative propagation. What's more. , alternative ratoon rice cultivation increases the planting index per year, from 1 time to 2 times or from 2 times to 3 times [4]. To increase the yield of ratoon it is necessary to make efforts so that ratoon shoots emerge from the remaining stems that are in and on the soil surface so that These shoots can give birth and take new roots like transplanted seeds, rather than shoots that grow at the end of the stems from the harvest and just a continue the remaining life of the previous plant 
without the addition of shoots (tillers) with new roots that die hanging and this results in low yields.

To stimulate the emergence of ratoon shoots from within and from the soil surface, it can be done by cutting the stems low at harvest, cutting down the stems or pruning the stems after harvesting so that they are closer to the soil surface. The effect of breaking down the stems by means of braiding. The result is 3.6 tonnes of GKG / ha higher than the cut $20 \mathrm{~cm}$ from the ground. The effect of stump trimming was reported by [5]. It turned out that the yield of ratoon increased by 5-6 $\mathrm{t} /$ ha and the number of tillers increased 2-3 times[6], pruning re-harvested stems as high as $3-5 \mathrm{~cm}$ from the soil surface (dpt) can trigger ratoon shoots on the remaining stems on the ground just like transplanted seedlings (give birth and continue to give birth) with yields increasing up to $25 \%$ according to the fertilizer dosage. added. ratoon can increase grain yield per unit area [7].

\section{EXPERIMENTAL PROCEDURE}

This study used a completely randomized experimental design (CRD) which consisted of two factors. The first factor is inundation height $(\mathrm{T} 0: 0 \mathrm{~cm}$ from the ground, $\mathrm{T} 1: 5 \mathrm{~cm}$ from the ground, T2: $10 \mathrm{~cm}$ from the ground, $\mathrm{T} 3: 15 \mathrm{~cm}$ from the ground) and the second factor is the inundation time (P1: Week 5 after pruning, P2: 6th week after pruning, P3: 7th week after pruning, P4: 8th week after pruning).

Each treatment was repeated 3 times, then a combination of $4 \times 4 \times 3=48$ experimental units was obtained. Observation data were analyzed using variance and $\mathrm{F}$ test which saw the real effect and then further tested with the Duncan Multiple Range Test (DMRT) at 5\%. The maintenance and harvesting of ratoon plants in this experiment include: embroidery, weeding, irrigation, fertilizing, and controlling pests and diseases. Water was given randomly at the beginning of growth and began to be inundated with a standing height according to the treatment.

The procedure for observing growth and yield in this experiment covers the following: Plant height $(\mathrm{cm})$, Maximum tiller (stem), Productive tiller (stem), , Number of grains per panicle (grain),Weight 1000 seeds (grams) and Grain yield per hill (grams) per hectare.

\section{RESULT AND DISCUSSION}

\section{A. Plant Height (cm)}




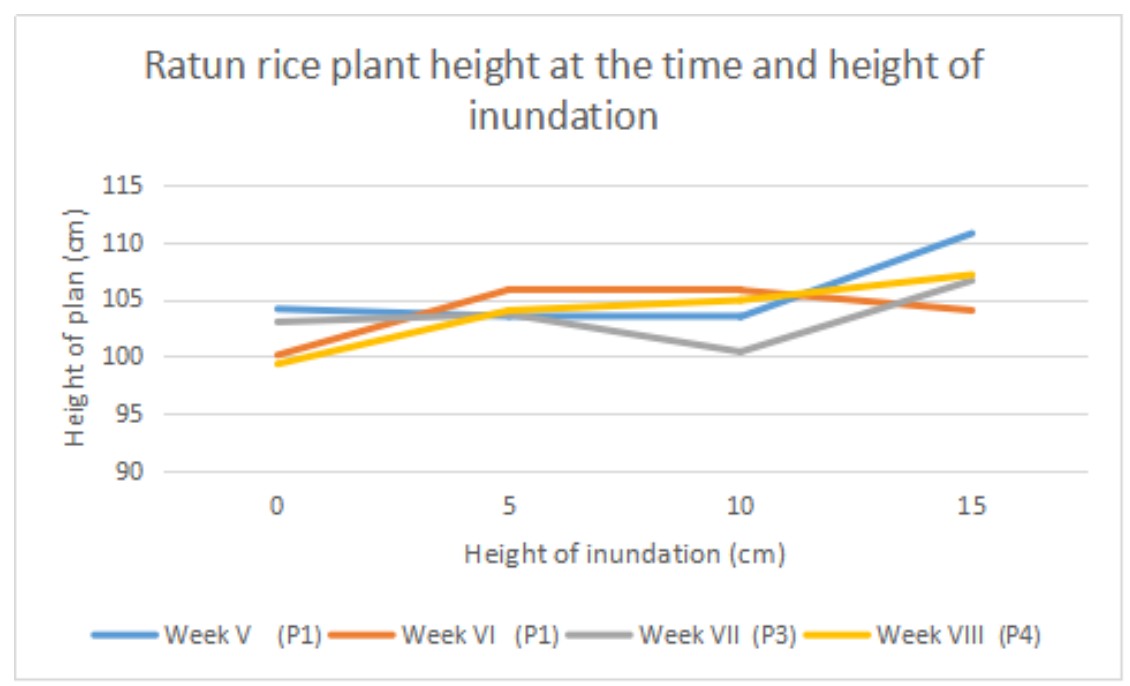

Graph 1. ratoon rice plant height at the time and height of inundation

Ratoon rice plant height of IR.42 variety was not determined by the starting time of inundation and inundation height by interaction or a single factor. There is no effect of treatment on the height of ratoon rice plants because genetic factors are more dominant on plant height than environmental factors. The optimum environmental conditions in this experiment did not cause a difference in plant height due to adequate supply of nutrients and water. in this study the plant height increased higher to $99.33-110 \mathrm{~cm}$. This proves that inundation is able to suppress lateral growth in this case is the growth of tillers and triggers vertical growth, namely the height of the plant, this occurs because the energy retained for tiller growth is partitioned to increase plant height growth in the vegetative phase and reproductive growth in the generative phase.

\section{B. Maximum Till (stem)}

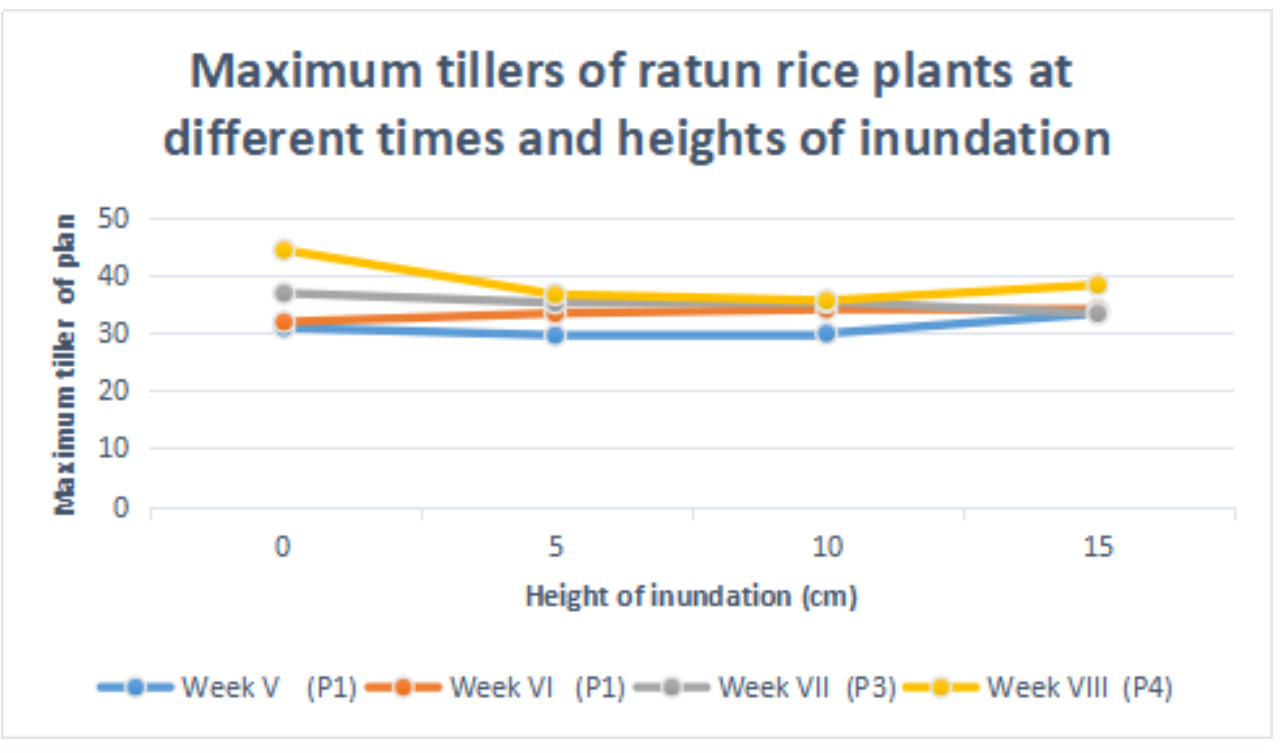




\section{International Journal of Agriculture, Environment and Bioresearch}

Vol. 5, No. 05; 2020

ISSN: $2456-8643$

Graph 2. Maximum tillers of ratoon rice plants at different times and heights of inundation

The average number of ratoon maximum tillers was not influenced by the starting time of inundation and the height of the inundation simultaneously or by a single factor of inundation height, but was more influenced by a single factor in the start of inundation. The maximum number of tillers increases as the time of inundation begins. The sooner the inundation starts, the less the number of tillers, this proves that standing water plays a role in limiting the number of tillers that will grow, because standing water makes it difficult for shoots to come to the surface due to limited energy for shoots to grow due to obstruction of the respiration process due to limited oxygen availability in water.

\section{Productive Till (stem).}

The average productive tillers of ratoon rice were not affected by the starting time of inundation and inundation height simultaneously as well as a single factor of inundation height, but were influenced by a single factor from the start of inundation. The same is the case with the maximum number of tillers, that the postponed the start of inundation time, the more productive tillers will be increased. In addition to limiting the maximum number of tillers, inundation also limits the number of productive tillers. This is related to the percentage of productive tillers which are almost the same resulting in linear inundation with the maximum number of tillers and the number of productive tillers.In accordance with the description of the rice plant variety IR 42 , the number of productive tillers is $24-25$ stems. Inundation height affected the number of productive tillers, the average height of inundation that produced the highest productive tillers was $0 \mathrm{~cm}$, followed by $15 \mathrm{~cm}$ at the time of inundation starting at week VIII.

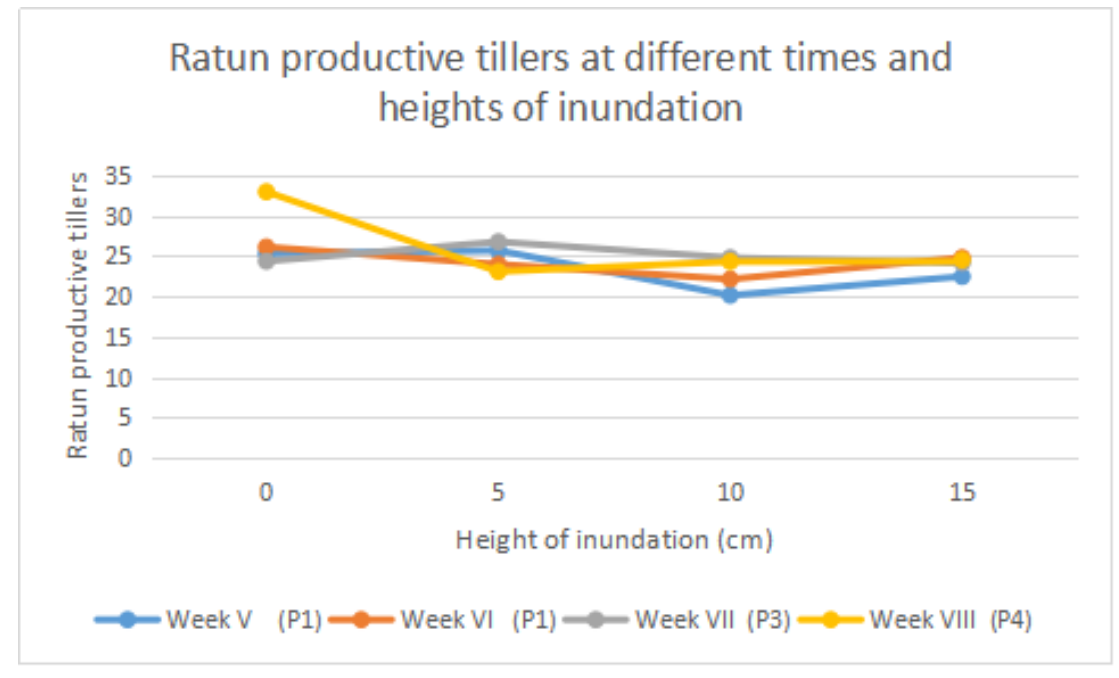

Graph 3. ratoon productive tillers at different times and heights of inundation

\section{Amount of grain (grain)}


Vol. 5, No. 05; 2020

ISSN: $2456-8643$

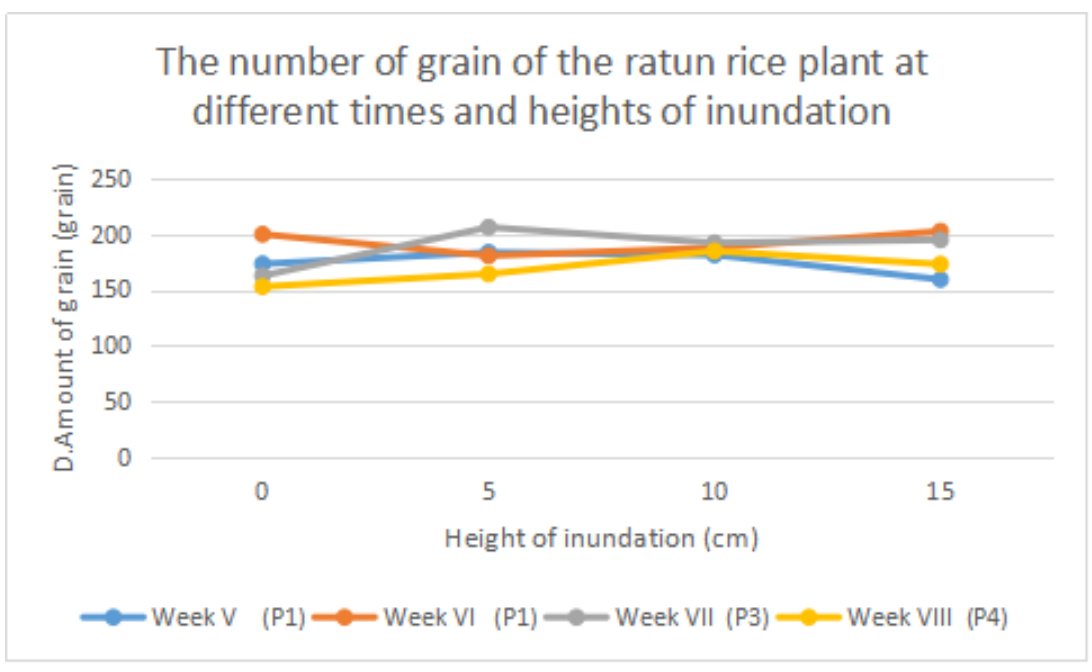

Graph 4. The number of grain of the ratoon rice plant at different times and heights of inundation

Environmental factors in the form of nutrients or nutrients and sufficient water make the growth of ratoon rice plants in normal conditions so that the treatment from inundation time and height of inundation does not affect the number of permalai grains. The number of grains per panicle of ratoon rice variety IR. 42 was not influenced by the time of inundation or inundation height because it was more influenced by genetic factors than environmental factors. Environmental factors in the form of nutrients or nutrients and sufficient water make the growth of ratoon rice plants in normal conditions so that the treatment from inundation time and height of inundation does not affect the number of permalai grains. however, if it is related to productive tillers, the weight of 100 grains and pithy rice will affect the subsequent grain yield.

As the results of the research [8], the cultivar rice can produce well in an inundation of less than $10 \mathrm{~cm}$, so that the availability of water for the metabolic process is sufficient which will support an increase in yield components and rice yields. The number of unhulled rice is directly proportional to the number of panicles at the cooking stage, so the number of clumps will determine the overall yield, this can be seen from the results achieved by the $4: 1$ and $5 \mathrm{~cm}$ inundation height gives consistent results, both the number of panicles. as well as the number of grains per panicle.

\section{E. Weight of 1000 seeds (grams)}




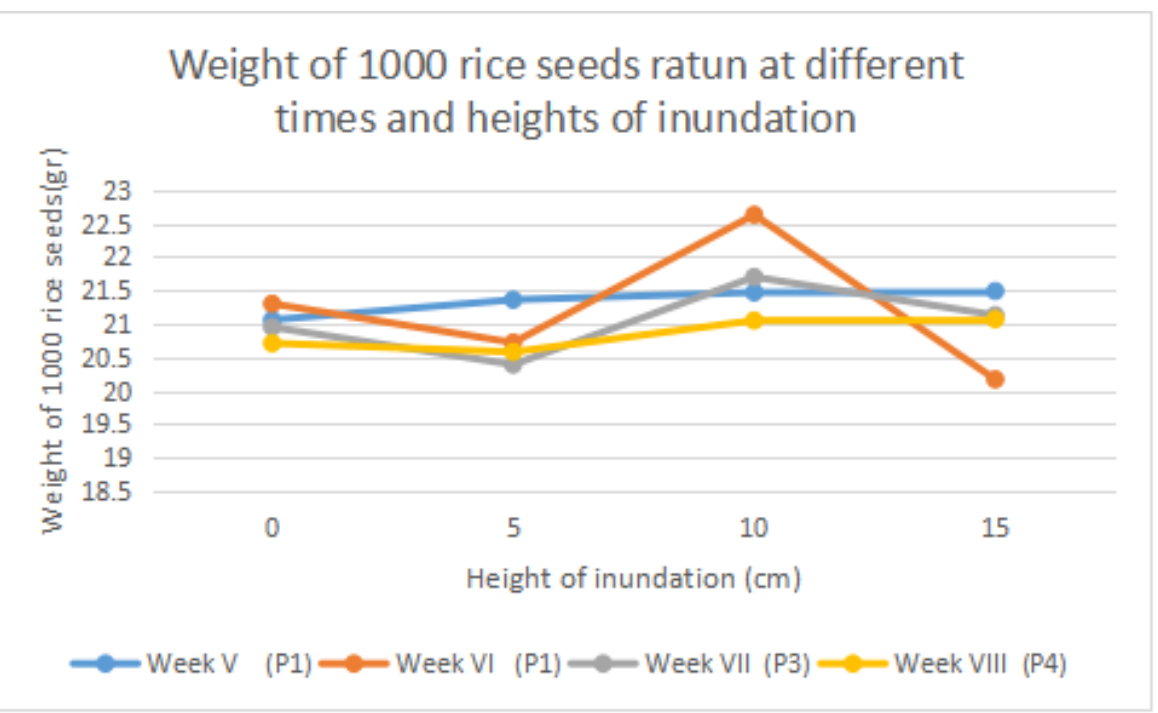

Graph 5. Weight of 1000 rice seeds ratoon at different times and heights of inundation

Inundation height up to $10 \mathrm{~cm}$ from the soil surface gives the highest weight of 1000 seeds, increasing the inundation height to $15 \mathrm{~cm}$ from the soil surface again reduces the weight of 1000 seeds as well as the weight of 1000 seeds at a water height of $0 \mathrm{~cm}$ and $5 \mathrm{~cm}$. This shows that the height of $10 \mathrm{~cm}$ is the height of water that is sufficient for the plant to supply water needs both as a nutrient solvent, translocation, metabolism, compiler cells, evaporation and evaporation. The water level exceeds up to $15 \mathrm{~cm}$ causes the plants to become saturated with water and sinks so that the plants are deprived of oxygen and it is difficult to metabolize to obtain energy for growth and yield.

\section{F. Grain of yield (gram / clump) (ton / ha).}

The weight of grain per clump is getting higher until the water level is $10 \mathrm{~cm}$ above the ground and begins to decline again with the addition of the inundation water level of $15 \mathrm{~cm}$ from the ground surface but still the same as $10 \mathrm{~cm}$ of inundation water surface. Similar to the weight of 100 grains (graph 5), the water surface height of $10 \mathrm{~cm}$ is the optimal for water level to meet the water needs of IR.42 ratoon rice, both for metabolism and evaporation. The addition of the water surface height up to $15 \mathrm{~cm}$ causes the plants to become saturated with water so that it disturbs the metabolic activity of the ratoon rice plant. The weight of grain per clump is getting higher until the water level is $10 \mathrm{~cm}$ above the ground and begins to decline again with the addition of $15 \mathrm{~cm}$ of inundation water surface height from the ground but still the same as $10 \mathrm{~cm}$ of inundation water surface. The addition of the water level up to $15 \mathrm{~cm}$ causes the plants to become saturated with water so that it interferes with the metabolic activity of the ratoon rice plant 


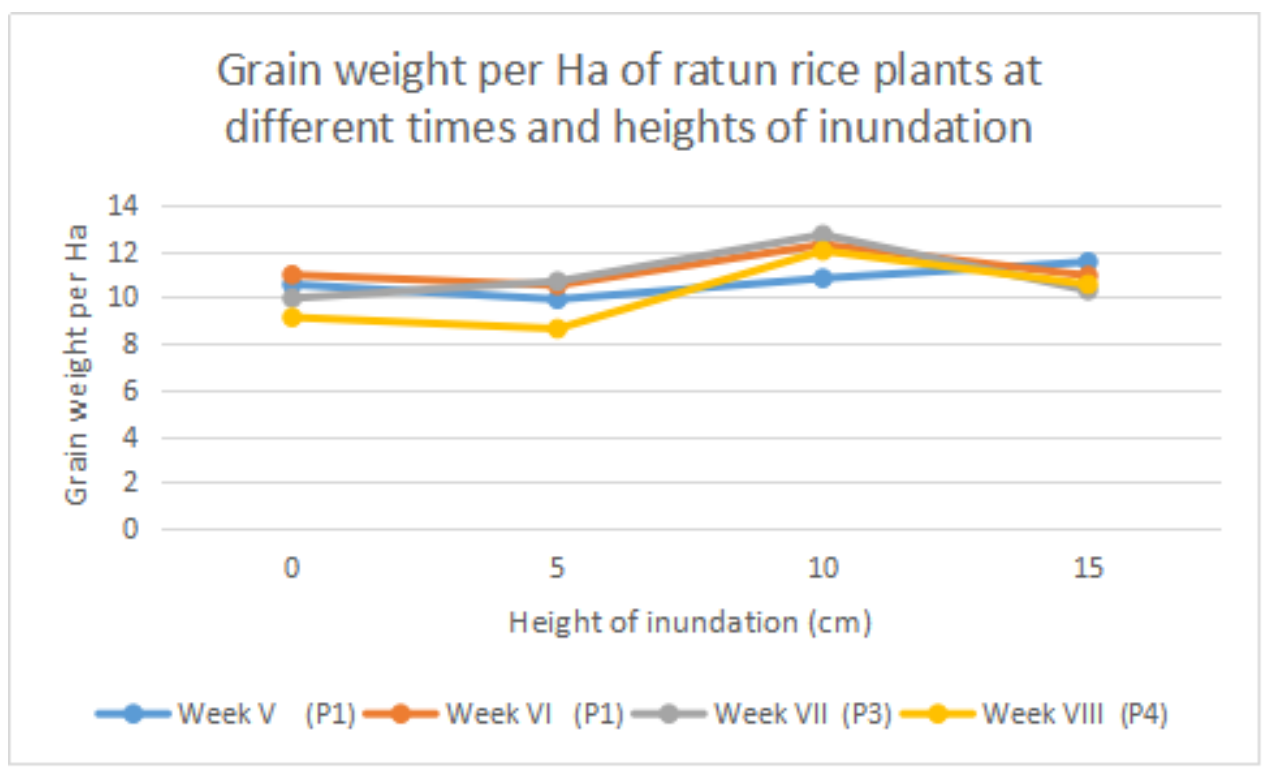

Graph 6. Grain weight per Ha of ratoon rice plants at different times and heights of inundation

Continuous shallow inundation immediately after harvest of the main crop gives better grain yields than delayed irrigation. This is related to the ability of plants to adapt due to inundated environmental conditions so that varieties that are tolerant of puddles are born and have the ability to tolerate and have high yield potential. IR 42 varieties is a variety that is suitable to be planted in lowland areas and tolerant to be planted in swamp areas, namely land that is always inundated by water.

In submerged conditions, rice plants that have high starch reserves will be better able to survive. The starch reserves present in plants must first be converted into simple sugars to be utilized. In rice sprouts treated with anoxia, there are many $\alpha$-, $\beta$-amylase, $\alpha$-glucosidase, debranching enzymes, maltase for starch degradation processes through glycolysis. In submerged rice plants: the concentration of $\alpha$-amylase and starch phosphorylase increased.

The alcohol dehydrogenase ( $\mathrm{ADH})$ enzyme has a very important role for rice seeds to germinate in stagnant conditions. In tolerant plants, it turns out that the ADH enzyme content is relatively higher, so that it is more resistant to stagnation in the seed germination phase[9]. After being submerged, rice plants experience sudden normal conditions, and can cause oxidative damage due to the presence of reactive $\mathrm{O} 2$ groups such as: $\mathrm{O} 2-, \mathrm{H} 2 \mathrm{O} 2$ and $\mathrm{OH}-$. This condition causes damage to cellular membranes and organelles due to the oxidation of unsaturated nitric acid in the lipid bilayer membrane, resulting in membrane leakage which affects the process of mitochondrial respiration and carbon fixation in chloroplasts. Rice plants have a mechanism to reduce this effect through activation of antioxidative enzymes (catalase (CAT), superoxide dismutase (SOD), ascorbate peroxidase (APX), monodehydroascorbate reductase (MDAR), dehydroascorbate reductase (DHAR), and glutathione reductase (GR)[10].

\section{CONCLUSION}


Vol. 5, No. 05; 2020

ISSN: $2456-8643$

The time to start flooding affects the maximum tillers and Productive tillers, the higher the tillers the longer the inundation starts. The highest productive tillers were in the 5th week of inundation and the best height for rice grain yields IR. 42 was $10 \mathrm{~cm}$.

\section{REFERENCES}

[1]. Kailou Liu1,2, Jiangtao Qin1*, Bin Zhang3 and Yanwen Zhao2 1Institute. 2012. "Physiological traits, yields and nitrogen translocation of ratoon rice in response to different cultivations and planting periods." African Journal of Agricultural Reseearch 7 (16): 2539-45. https://doi.org/10.5897/AJAR10.416

[2]. Mareza, E, Z.R. Djafar, R.A. Suwignyo dan A. Wijaya. 2016. Rice Ratoon Yield Response To Main Crops Cutting HeightIn Tidal Swamp Using Direct Seeding System. Agrivita Journal of Agricultural Science. 38(2): 126-132

[3]. Shin, Jong Hee, Sang Kuk Kim, dan Sang Gu Park. 2016. "Effects of Stubble Height , Irrigation and Nitrogen Fertilization on Rice Ratooning in Korea," 1-4.

[4]. Santoso, Marhaenis Budi. 2014. "Ratun Cultivation." Binuang Agricultural Training Center, 1-7. http://www.bbpp-binuang.info/uploads/files/ Ratun Cultivation.pdf.

[5]. Thuamkham, C. Pojananuwong, S. 2003. Ratoon Cropping of Lodged Stubble. The Office of Agricultural Research and Development Region 5, Sapaya District, Chainat Province, Thailand.

[6]. Erdiman, Nieldalina, dan Misran. 2012. Increased Land Productivity through Development of Salibu Rice Technology. Final Report of the West Sumatra BPTP Research Team. Page 25.

[7]. Santos, A.B., N.K. Fregeria dan A.S. Prabu. 2003. Rice Ratooning Management Practices for Higher Yield. Commun. Soil Sci. Plant Anal. 34:881-918.

[8]. Bahua, M. I., \& Gubali, H. (2020). Direct seed planting system and giving liquid organic fertilizer as a new method to increase rice yield and growth (Oryza sativa L.). AGRIVITA Journal of Agricultural Science, 42(1), 68-77. https://doi.org/10.17503/agrivita.v42i1.2324

[9]. Torred, M.B. (2017). Formulation and utilization of liquid biofertilizers and their effect on the growth and yield performance of adlay (Coix lacryma -jobi L.)(Doctoral dissertation). Central Mindanao University, Musuan, Bukidnon, Philippines

[10]. Pasaribu, P.O., Triadiati \& Anas, I. (2018). Rice Ratooning Using the Salibu System and the System of Rice Intensification Method Influenced by Physiological Traits. Pertanik J Trop Agric Sci, 41(2), $637-654$ 